\title{
The Application of Information Technology in Teaching Management of Universities and Colleges in the Background of Internet Plus
}

\author{
Jiancui Ma \\ Hunan Modern Logistics College \\ Changsha, China 410131
}

\author{
Jing Zhong* \\ Hunan Modern Logistics College \\ Changsha, China 410131 \\ *Corresponding Author
}

\begin{abstract}
In the era of "Internet Plus", the current students in colleges and universities are much dependent on the Internet. In order to improve the quality of teaching, colleges and universities have adopted the information technology in teaching methods and teaching management, and relevant departments in teaching have also adopted information technology in the process of teaching supervision and management. In this paper, we have analyzed the current application of information technology in universities and colleges, and put forward ideas and measures for the application of information technology.
\end{abstract}

Keywords-information technology; teaching management; measures

\section{INTRODUCTION}

At present, in order to adapt to the rapid development of the "Internet+" era, adapt to students' living, learning and communication methods, and increase students' interest in learning, colleges and universities have made many changes in their teaching management and applied more and more information technologies in the teaching management. For example, there are MOOCs, Micro-lectures, WeChat public platforms, comprehensive educational management system, digital campus, the construction of resource libraries, etc., which have brought great changes to the teaching management of colleges and universities.

\section{THE BACKGROUND OF THE APPLICATION OF INFORMATION TECHNOLOGY IN THE TEACHING MANAGEMENT OF COLLEGES AND UNIVERSITIES}

"Internet + " is the trend of social development, which brings opportunities as well as challenges for the development of teaching management in colleges and universities. First, many new media and technologies have been developed and applied. Secondly, universities and colleges have established a scientific teaching management philosophy, and gradually learn to innovate their teaching management modes according to the teaching needs.

- In the era of "Internet+", students' lifestyles, ways of communication, and ways of acquiring knowledge have changed a lot. So the traditional teaching method can no longer meet the needs of students in learning and cannot increase students' interest in learning. The rapid development of the Internet has made students' ability to accept new things improved and have made them become more eager for new things. Therefore, the student-centered MOOCs, flipped classrooms, micro-lectures, etc. have emerged in the wave of teaching reforms, aiming at changing the teaching management mode and improving the quality of teaching.

- In the era of "Internet+", the channels for students to obtain resources have become more, and the amount of information that students are exposed to is large. The application of information technology can make the resources more rationally distributed and fully shared, so that students can have access to the resources provided by their own schools as well as other schools and the domestic and foreign resources. Through the use of information technology, students can choose more and better resources according to their own learning ability and learning interest, and the personalized education and personalized development of students can be truly achieved.

- The school-enterprise cooperation and the integration of production and education have been implemented, which has changed the traditional education model with school as the single subject. The school and the enterprise jointly cultivate talents, and the dualsubject and multi-regional training model is applied to educate students. In this education model, it is necessary to use information technology to timely access student information.

- The relationship between college teachers and students is not like that between primary and secondary schoolteachers and students. In the primary and secondary schools, there is too much after-school tutoring time and links. In college, most of the teachers have few opportunities to meet with students after class. Therefore, it is difficult for students to give feedback to the teacher in time when encountering problems that they cannot understand, 
which has decreased students' interest in learning. If the information technology is used, the interaction between students and teachers can be increased to a certain extent, the distance between students and teachers can be closed, and the teaching effect can be improved.

\section{THE PROBLEMS EXISTING IN THE APPLICATION OF INFORMATION TECHNOLOGY IN THE TEACHING MANAGEMENT IN COLLEGES AND UNIVERSITIES UNDER THE BACKGROUND OF "INTERNET+"}

\section{A. The Passiveness of the Application of Information Technology in Teaching Management in Colleges and Universities Under the Background of "Internet+"}

In order to meet the needs of teaching management, adapt to the changes of the times, and adapt to students' living and communication habits, colleges and universities are currently using information technology in the process of management and operation. For example, the information technology is used in new students' admission statistics, teaching arrangements, financial payment, employment statistics, daily affair processing, etc. The use of information technology has made it convenient to carry out our work. However, due to the current inferior state of information construction in colleges and universities, they usually choose to purchase the generalized external system to apply information technology, which can reduce the costs of construction and accelerate the process of information construction. However, because the system is externally developed, the schools are in a passive state in the process of using it. They can only deal with the matters in teaching management according to the processes designed to deal with enterprise development matters. This kind of system does not reflect the characteristics of the schools themselves. And the system cannot be timely adjusted and updated according to the corresponding changes in the teaching methods. However, the current education model with schoolenterprise cooperation and the integration of production and education requires the schools' teaching management to be diversified and personalized, and the passive selection of external systems cannot achieve a diversified and personalized teaching management model.

\section{B. Poor Openness of the Application of Information}

Technology in Teaching Management in Colleges and Universities Under the Background of "Internet+"

The era of "Internet + " is an era in which information is open and shared. However, most of the information technologies applied to teaching management of colleges and universities can only be used within the school. As for the teaching information that the relevant departments need to obtain, such as the information on students' changes and students' employment, they cannot be shared by the school and the relevant departments. For example, the annual collection of teaching information of colleges and universities, such as the collection of students' employment information, is originally an understanding of the daily teaching management of the school by the relevant department. But because of the different channels and different systems used, the simple data acquisition becomes the editing of a large amount of data, which has not only not reflected the convenience brought by information technology, but also made the data acquisition become a burden for both the school and relevant department. Moreover, the authenticity of the re-edited data is greatly reduced, and it is very likely that relevant departments will not obtain the real regulatory information. The data editing forms in different department systems are usually different, which will probably lead to repeated editing of the same data, increasing the daily workload.

\section{Insufficient Application of Information Technology in the Context of "Internet+"}

At present, the application of information technology in the teaching management of colleges and universities is not thorough enough to reflect the convenience of information technology. (1) The use of information technology can make the teaching affairs dealt with online, which is environmentally friendly, achieving the paperless office processing mode that is advocated. However, the goal to realize paperless office is not yet achieved in the current teaching management of most colleges, and the paperless submission is not yet realized in many processes; (2) in the teaching process, because the system is externally purchased, its update and upgrade speed cannot meet the requirements of current higher vocational teaching reform under schoolenterprise cooperation and integration of production and education, nor can it catch up with the speed of teaching mode reform. And teachers cannot well use the information means in their teaching; (3) currently, in the process of teaching management, various departments of colleges and universities have not communicated and interconnected with each other well, and there is not a unified standard for the sharing of process information and resources, making resource integration more difficult to achieve.

\section{IDEAS AND MEASURES FOR THE APPLICATION OF INFORMATION TECHNOLOGY IN THE CONTEXT OF "INTERNET+"}

\section{A. The Idea of Using Information Technology in the Teaching Management of Colleges and Universities Under the Background of "Internet+"}

The teaching resources should be fully interactive and integrated through the information-based teaching management system, and the open, collaborative, integrated, innovate and shared win-win information platform should be built combined with the internal relations between the various sections of the college teaching management and the external relations between the regulators and the schoolenterprise partners. The LAN, mobile internet, and Internet of Things can be used to serve teachers' teaching, achieve school-enterprise information exchange, and realize the connection between school and supervisory information resources. The daily management data of the school can be modified and generated in the daily work record of the school, and the relevant management department can directly 
get the information they needed through the platform. It is no longer needed for the school to edit the data according to the system mode of the department and the needs of the management department before reporting the data to the department. That is, the relevant parties in the teaching management of colleges and universities should have data transmission channels or shared information platforms. Data statistics can be saved in the daily work record, data modifications can be saved on the information platform, or data can be shared directly for review. The relevant departments can get the information they need directly on the platform, and the data they get is real and there is no duplication of work.

\section{B. Measures for the Application of Information Technology in Teaching Management Under the Background of "Internet+"}

1) Strengthening the information construction of the colleges and universities themselves: The rapid development of Internet technology has made it possible for colleges and universities to establish flexible and diverse teaching management mechanisms, and has also promoted the teaching reform. The knowledge and ability of teachers to apply information technology in the teaching process is the basis for informationization. The technologies should be kept pace with the times, adjusted and updated in time, and be able to complete the teaching management work quickly and accurately, and respond to the needs of college teaching management in a timely manner. In order to fully play the role of information technology in their teaching management, colleges and universities should take the initiative to research and develop their own management systems, and update them according to the characteristics of the schools to meet the needs of teachers and students. This has, to a certain extent, overcome the shortcoming of the external teaching management system to not be able to respond in time due to its reliance on third parties.

2) Building a common information platform of colleges and related parties to achieve information sharing: In this way can the information of colleges and universities be supervised and managed by the relevant parties. The school plays a role in accumulating data. The daily teaching data and student data should be input, modified and formed by the school in the daily teaching management process. A shared information platform should be established for the relevant parties to collect and acquire information resources of colleges and universities. The daily data of colleges and universities are shared on this information platform. The management department can obtain information resources at any time on the platform without the need of the school's data editing and submitting. And the data they acquire through the platform is true. The online approval process and system should be standardized to enable the school to deal with the applications for student scholarships and various teaching projects through the Internet, and the electronic declaration and approval mode should be adopted to achieve paperless office.

(3) Establishing external functional ports and standardize the functional practice flow of information integration. The top higher vocational colleges have adopted the education mode of school-enterprise cooperation. The talent training programs are jointly developed by the schools and enterprises which are both the main venues for students to learn knowledge and skills. The processes of cognitive learning, theory learning and enterprise practice learning of students are not completely independent; instead, they are a whole process for students to achieve mutual integration and gradual progress. The school should establish a docking port with the enterprise. In the teaching process, the teacher can obtain the enterprise information and use the practical data to prove the theoretical knowledge. Moreover, schools and enterprises are both responsible for the management of students, and the information sharing will make it easier for them to manage students.

\section{CONCLUSION}

In short, in the context of "Internet+", colleges and universities need to adopt new ideas, use modern concepts, and apply advanced teaching management methods in their teaching management, and use information technology to meet the current students' craving for new technology. The information technology should be applied to increase students' interest in learning, improve the teaching quality, improve teaching management, simplify work processes, and improve work efficiency, thus achieving a scientific teaching management system.

\section{REFERENCES}

[1] Pang Zhaojun, Liu Guoyong. Innovation and Practice of Teaching Management System in Colleges and Universities [J]. Modern Communication, No. 17 of 2018. (in Chinese)

[2] Chen Weipeng. Research on Information-basedTeaching Management of Higher Vocational Colleges Based on Smart Campus[J]. Journal of Heilongjiang Institute of Education, September 2018. (in Chinese)

[3] Xiu Xiaoqi. The status quo and thinking of information-based teaching management in higher vocational colleges $[\mathrm{J}]$. Ability and Wisdom, 2018. (in Chinese)

[4] Xu Meiyan. Application Strategy of Information Technology in Classroom Teaching and Management in Higher Vocational Colleges [J]. Light Industry Science and Technology, No. 5, 2018. (in Chinese) 